\title{
The Influence of the Debt Ratio and Enterprise Performance of Joint Stock Companies of Vietnam National Coal and Mineral Industries Holding Corp.
}

\author{
Thi Thuy HOANG ${ }^{1}$, Lien Thi HOANG ${ }^{2}$, Thi KimThu PHI $^{3}$, Minh Thu NGUYEN ${ }^{4}$, Minh Quang PHAN ${ }^{5}$
}

Received: August 01, 2020 Revised: September 06, 2020 Accepted: September 10, 2020

\begin{abstract}
:
This objective of this study is to enrich the literature by the debt ratio and enterprise performance of Joint stock companies of Vietnam National Coal and Mineral Industries Holding Corporation Limited (Vinacomin). The debt ratio is an important index of capital structure, and it influences and decides the enterprise performance. Therefore, the determination of reasonable debt ratio level is beneficial to the stable operation of Vinacomin's enterprises. Based on the research conclusion about the effect on capital structure of debt ratio from domestic and foreign scholar, collecting data from 2014-2018 of Vinacomin's enterprises as a research sample, the article conducts research on the relationship between debt ratio and business performance of Vinacomin, as measured by return on total Assets. In addition, the study uses free cash flow, company size, growth opportunity, investment opportunities, operating costs to sales ratio as control variables. The study shows the debt ratio of Joint stock companies of Vietnam National Coal and Mineral Industries Holding Corporation Limited has a negative effect on the enterprise performance. Furthermore, the research results of the article are references for Vinacomin' enterprises in the course of production and business activities, determining a reasonable debt ratio, and improving the operational performance of enterprises.
\end{abstract}

Keywords: Capital Structure, Debt Ratio, Enterprise Performance, Vinacomin

JEL Classification Code: G32, G39, L25, L71

\section{Introduction}

When the businesses conduct its operations, it requires capital to do so. All businesses must have capital in order to purchase assets and maintain their operations. The enterprises must arrange the appropriate funding for the

${ }^{1}$ First Author and Corresponding Author. Hanoi University of Mining and Geology, VietNam [Postal Address: No.18 Vien Street - Duc Thang Ward, Bac Tu Liem District, Ha Noi, 100000, Vietnam] Email: thuyhumg.hoang@gmail.com

${ }^{2}$ Hanoi University of Pharmacy, Viet Nam.

Email: Lienht88@gmail.com

${ }^{3} \mathrm{H}$ anoi University of Mining and Geology, VietNam.

Email: phithikimthu2011@gmail.com

${ }^{4} \mathrm{PhD}$ Student, Hanoi University of Mining and Geology, VietNam.

Email: nguyenthu2012@gmail.com

${ }^{5}$ Lecturer, Hanoi University of Mining and Geology, VietNam.

Email: Phanminhquang061290@gmail.com

(c) Copyright: The Author(s)

This is an Open Access article distributed under the terms of the Creative Commons Attribution Non-Commercial License (https://creativecommons.org/licenses/by-nc/4.0/) which permits unrestricted non-commercial use, distribution, and reproduction in any medium, provided the original work is properly cited. capital requirement. There are many funding sources for the capital of enterprises such as: Owner's equity capital, short term loan, long term loan. The capital structure has an impact on the business performance of the company, therefore the companies need to plan the structure of reasonable capital. According to the theory of Modigliani and Miler (1958), there does not exist an optimum capital structure for each enterprise, however the conclusion of Modigliani and Miler (1958) is not yet practical because of the issues arising from the conflict of representation within the business and other factors that affect the decision making on the structure of the corprate capital. Modigliani and Miler have pointed out that the aggregate impact of such factors such as taxation, and the cost of intermediate when using debt with opposite effects form the theory of optimum financial structure. When a company wishes to establish a long-term funding source, the loan cannot be ignored such as debt, isuing bonds (Dnaldson, 1961).

According to the traditional concept of optimum capital structure, when the business borrowed, the proportion between debt and equity increased, forcing the owners to increase the return on shareholder's requirement (i.e. 
the cost of equity increased). In addition, increasing debts can lead to rising production costs, thereby reducing the profitability of the business, and in the process, it reduces the operational efficiency of a business. In addition, when using debts, especially the short term debt, it is always associated with a bankruptcy risk when the business is insolvent. Therefore, according to the theory of optimum capital structure, the capital structure has an impact on the average cost of capital and firm value or in other words, when an enterprise has optimum debt proportions, the average cost of capital is the smallest and the firm value is the largest. In the process of integration into the international economy, joint stock companies of Vietnam national coal and mineral industries should continue to restructure, and enhance the competitiveness. Therefore the article clarifys the impact of capital restructuring on the enterprise which has the influence of the debt ratio on the firm performance of joint stock companies of Vietnam national coal and mineral industries, from there, there it was proposed that the capital structure policy contributed to improve joint stock companies of Vietnam national coal and mineral industries.

\section{The Relationship between Debt Ratio and Enterprise Performance}

In the world of globalization today, the perfromance of an enterprise is an important factor to measure the level of success and competitiveness of the company at present and in future times. Therefore, it is necessary to study the financial factors that affect the enterprise performance such as cash flow, financial leverage, investment level and other factors. One of the factors that is of interest to the scholars for discussions in the recent years is the capital structure, the researchs revolves around the influence of the capital structure on the investment activities of the enterprise, and the business efficiency of the enterprise. A high-debt ratio will affect the business results of an enterprise. This is also the issue for the authors who want to clarify the answer in Vietnamese enterprises especially the joint stock companies of Vietnam national coal and mineral industries. The debt ratio of the company are the financial indicators reflecting the financial scale of the company, which is mentioned in the structure of the capital of the enterprise showing how many are mobilized from the loan source.

The study of the relationship between the ratio of debt and the performance of the company has been discussed by many scholars, and the results of the study are different, which mainly arises form three groups of perspectives: The first: The debt ratio and enterprise performance have a positive relationship. According to the theory of capital optimization, when the enterprises mobilize loan sources, it reduces the cost of capital utilization and increases the market value of enterprises, therefore the enterprises should use the debt funds for payments to optimize capital structure. According to Zeitun (2007), research on capital structure and performance of the enterprises indicates that the proportion of shortterm debt ratio in the total assets has a positive effect on the performance of the enterprises. It means that the higher the short-term loans taken by the enterprise, better the effect on the growth rate. Berger (2006) based on the basis of the agency theory of Jensen and Meckling (1976), conducted research on the capital structure and firm performance. The results suggested that enterprises which has a higher debt ratio had smaller agency costs, which results in an increase in the firm performance. With another research perspective, Dong (2007)points out that, when enterprises have corporate income tax, capital structure related to the value of the Enterprise (Modigliani \& Miller, 1963). The advantage of using debt is to be able to save taxes because the cost of debt is a reasonable cost to be deducted from the pre-tax profit. Therefore, the value of the business is increased by the benefit from the tax shield. The results of research in the company which has high debt rates, the financial levergate and the enterprise performance show the same-dimensional relation, however in the construction model, the factors affecting the outcome of the business consider only the influence of the company size and the proportion of fixed assets of the company without considering other factors such as the growth rate, the cash flow. The companies when borrowing will try to take advantage of the growth opportunity to increase corporate profits, thereby increasing the firm performance (Dessi, 2003)

Second is the group of perspective that the debt radio and enterprise performance have a counter-dimensional relationship. Most research in the country such as by Tran (2017) and foreign studies such as by Majumdar (1999), Onaolapo (2010), Zhang (2017) have pointed that an increase in the debt rate of the company leads to a decrease in the enterprise performance. According to Tran (2017) while he studied the relationship between capital structure and financial operations, the author clearly analyzes the choice of the capital structure of the firms that can transmit signs to the investor who has otherwise no information about the firm. Enterprises which increase the rate of debt and if the information is transmitted outside, can create unfavorable factors for the business, affecting the mobilization of capital and in turn influencing the financial situation and the results of the operation of the business. The results showed that the company's debt ratio and financial performance of the company (the return on equity) had a counter-dimensional relationship. In the conversion economies, the results showed that the financial performance of the company had an inverse relation to the debt rate (Braduri, 2002), the debt ratio on total assets has a negative correlation with the profitability of the company (Majumdar, 1999). 
According to the research of Onaolapo (2010) who collected the figures of 30 financial companies listed on the Nigerian Stock Exchange from 2001 - 2007 for conducting research on the relationship between debt ratio and firm performce, the results of the study indicated the rate of debt has an impact on firm performce. As the corporate debt ratio increases, the percentage of profits on the total assets and profits on a stock tends to decline, in this conition the company's financial structure and the firm performance have a negative relationship (Zhang, 2017). Mo (2008) used data from the real estate companies on the Chinese stock Exchange for the period 2003-2005 while conducting analysis and detection of the debt ratio of real estate companies on the stock market which showed a negative relationship with the firm performance. Tran (2017) who researched on the relationship between financial structure and financial performance of Joint stock company in Thua Thien Hue province pointed out that a business with a high ratio of debt showed a negative relationship with the return on equity. Businesses that want to progress need to balance the internal capital and the debt with higher equity ratio, aimed at avoiding business risk. Tran (2006) collects figures of small and medium enterprises in Vietnam for a period of $1999-2005$, he has pointed out that the firm performance has an inverse relationship with the debt rate but not statistically significant.

The third is a group of mixed perspectives which says that the debt rate that has a positive relationship as well as a negative relationship with the firm performance. Xiong (2013) analyzes the impact of the debt rate on the business efficiency of companies belonging to the automotive industry in China that has pointed the rate of debt has both a positive and a negative relational relationship with the results of the business outcome of the automobile enterprises. Research results show that a handful of businesses with a debt rate of $40-50 \%$ of the funding structure, the rate of debt had a positive relationship with the firm performance while rest of the enterprises showed a negative influence on debt ratio on the performance of the enterprise.

Empirical research results theoretically demonstrates that the percentage of debt has a positive or negative effect on firm performance, in other words, debt has both negative and positive impacts on the firm performance. Thus, the problem is necessary to study the trend of this influence in the joint stock companies of Vietnam national coal and mineral industries. On the basis of the current studies, most of the perspectives believe that the debt rate is negatively related to firm performance. With the actual situation of research in Vietnam, the author has based his view on the theoretical basis of capital structure which says that the enterprises use the loan to have the advantage of tax shield. When the cost of debt is low along with the tax shield, the business will have an advantage when they raise the debt level. A business with an unsuitable debt ratio will lack financial flexibility and will be sensitive to economic shocks, if the business falls too much into debt then it may also become difficult to borrow money to cover expenses. At the high debt to equity ratio, the cost of debt also increases so that the likelihood that the business will be unable to repay the debt also increases. At this time, the debt rate on the equity reduces the business efficiency. With the above analysis and argument the author makes the following assumption:

HO: The debt ratio has a negative effect on the enterprise performance.

\section{Research Methodology}

\subsection{Research Data}

Research data relating to dependent variables and independent variables are manually collected from audited consolidated financial statements and annual reports of the joint stock companies of Vietnam national coal and mineral industries period 2014-2018, with a total of 85 observations.

\subsection{Research Model}

Based on the previous studies and barking modified the study model of Majumdar (1999), Mo (2008), Onaolapo (2010), Tran (2017), the author of a proposed model of the impact of the debt ratio to enterprise performance of the joint stock companies of Vietnam national coal - mineral industries is reflected:

$$
\mathrm{Y}_{\mathrm{it}}=\alpha_{0}+\alpha_{0} L E V_{i t}+\sum_{k=0}^{k} \alpha_{k} X_{i t}+u_{i t}
$$

$\mathrm{Y}$ is the dependent variable, which measures the results of the research business using measurement criteria by the the return on Assets (Nguyen \& Nguyen, 2020). Explanatory Variable: LEV (Debt ratio) reflects the percentage of the company's debt (Nguyen \& Pham, 2019). The debt ratio is measured as total Debt / Total assets (Mukhibad et al, 2020). X are variables of control that affect the performance of the company. Based on the literature studies (Altuwaijri \& Kalyanaraman, 2020; Nguyen \& Nguyen, 2019; Rahman \& Saima, 2018), the variable control include: Free cash flow (FCF), Company size (Size), Growth opportunity (Growth), Investment opportunities (TobinQ), Operating costs to sales ratio (Oper), Time of years of enterprise Establishment (Year) (see Table 1). 
Table 1: Research and measurement variables research

\begin{tabular}{|l|l|l|}
\hline Sign & \multicolumn{2}{|c|}{ Variable name } \\
\hline 1. Dependent Variables \\
\hline ROA & Return on total Assets & Profit / Total Assets \\
\hline 2. Explanatory Variables & \multicolumn{2}{l|}{} \\
\hline LEV & Debt ratio & Total Debt / Total Assets \\
\hline 3. Control Variables & $\begin{array}{l}\text { (Profit + Depreciation - Capital expenditure - Change of working } \\
\text { capital)/Net revenue }\end{array}$ \\
\hline FCF & Free Cash Flow & Gross sales at year t dividied by gross sales in the previous year (t-1) \\
\hline Growth & Sale growth & Ln of total assets \\
\hline Size & Company size & (Toatal selling and administrative costs) / Gross Sales \\
\hline Oper & Operating costs to sales ratio & Market value of company / Total assets \\
\hline Tobin Q & Investment opportunities & Years of establishment \\
\hline Year & Time &
\end{tabular}

Table 2: Summary statistics

\begin{tabular}{|l|c|c|c|c|c|}
\hline Var & Obs & Mean & Std.Dev & Min & Max \\
\hline ROA & 85 & 0.0299181 & 0.025660 & 0.0002781 & 0.1671453 \\
\hline LEV & 85 & 0.7405122 & 0.179909 & 0.1512226 & 0.9281341 \\
\hline FCF $_{\mathrm{t}-1}$ & 85 & -0.145208 & 0.156964 & -0.5744301 & 0.3076146 \\
\hline FCF $_{\mathrm{t}}$ & 85 & 0.468707 & 0.150342 & -0.3285437 & 0.9346267 \\
\hline Growth & 85 & 1.041334 & 0.218438 & 0.0005027 & 1.463575 \\
\hline Size & 85 & 13.4458 & 1.12822 & 11.36896 & 15.24625 \\
\hline Oper & 85 & 0.0855242 & 0.39847 & 0.0122396 & 0.216448 \\
\hline Tobin Q & 85 & 0.8898514 & 0.155787 & 0.2874094 & 1.294057 \\
\hline Year & 85 & 1.548508 & 0.2216051 & 1.041393 & 1.763428 \\
\hline
\end{tabular}

The study uses three regression models for table data as follows: The Ordinary least square regression model (OLS model), Fixed effects models (FEM) and Random effects models (REM). Then proceed to the Hausman inspection and Breusch - Pagan LM Inspections to choose the appropriate model for the study. Next is test multicolllinearity, autocorrelation and heteroskesasticity, variance of change and cross-dependency for the chosen model to find out model defects. Ultimately the defect of the model will be corrected to ensure the reliability of the regression result.

\section{Empirical Results}

\subsection{Summary Statistics}

Table 2 describes the variables used in research papers including: Average value ROA of the joint stock companies of Vietnam national coal - mineral industries is
0.0299 , proved that in the period 2014-2018 the joint stock companies of Vietnam national coal and mineral industries operated effectively. In the period $2014-2018$ the debt rate on the total assets of the average company reaches 0.7405 (see Table 2).

This is a fairly high rate compared to other sectors in the Vietnam securities market. In 85 observations, businesses with a debt rate of less than $50 \%$ have only 9 observations, accounting for $10.6 \%$ of the total number of observations, while the remaining $89.4 \%$ of the observations have a debt rate of over $50 \%$ (Figure 1). This demonstrates the financial structure characteristics of joint stock companies of Vietnam national coal and mineral industries, mainly using the financial seven.

The coefficient of correlation between the variables presented in Table 3, the correlation coefficient is less than 0.8 , the average VIF index of 2.61, max value is 5.08 so it is possible that there is less likely to occur multicolllinearity phenomenon between variables. 


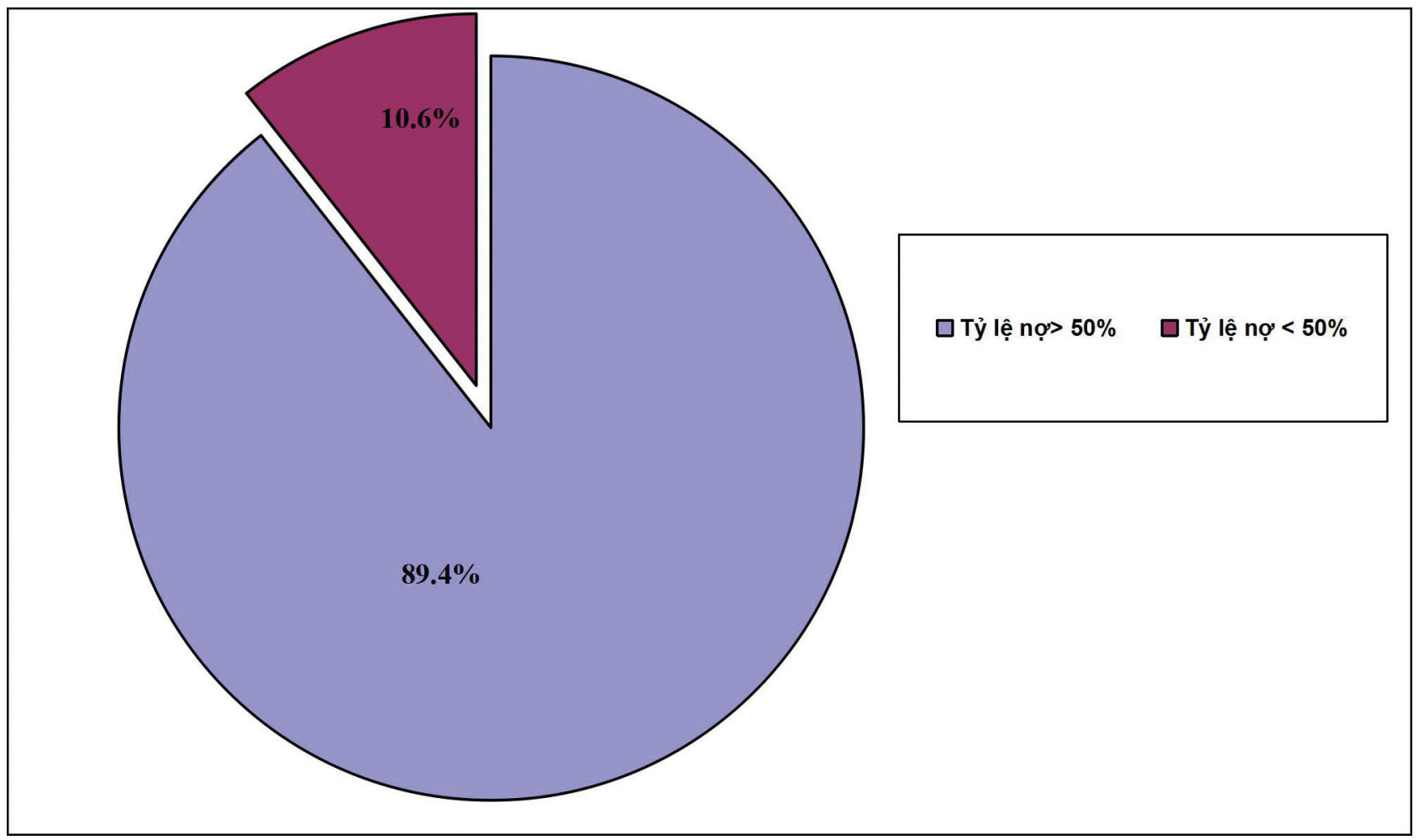

Figure 1: Survery form structure capiatal by debt rati

Table 3: Correlation coefficients

\begin{tabular}{|c|c|c|c|c|c|c|c|c|c|}
\hline Var & $\mathrm{ROA}_{t}$ & LEV $_{t}$ & $\mathrm{CF}_{\mathrm{t}-1}$ & $\mathrm{CF}_{\mathrm{t}}$ & Growth $_{t}$ & Size $_{t}$ & Oper $_{t}$ & Tobin $Q_{t}$ & Year $_{t}$ \\
\hline $\mathrm{ROA}_{\mathrm{t}}$ & 1 & & & & & & & & \\
\hline LEV $_{t}$ & $-0.77761^{* * *}$ & 1 & & & & & & & \\
\hline $\mathrm{FCF}_{\mathrm{t}-1}$ & 0.0641 & $-0.1989^{*}$ & 1 & & & & & & \\
\hline $\mathrm{FCF}_{\mathrm{t}}$ & 0.0045 & -0.0866 & $0.5613^{* * *}$ & 1 & & & & & \\
\hline Growth $_{t}$ & 0.1005 & 0.0211 & 0.0013 & $-0.4302^{* \star *}$ & 1 & & & & \\
\hline Size $_{t}$ & $-0.2932^{* * *}$ & $0.4081^{* * *}$ & $-0.3329^{* * *}$ & -0.1436 & 0.0479 & 1 & & & \\
\hline Oper $_{t}$ & $0.4393^{* * *}$ & $-0.6253^{* * *}$ & 0.1067 & 0.0140 & -0.1700 & $-0.4919^{* * *}$ & 1 & & \\
\hline Tobin $_{t}$ & $-0.5044^{* * *}$ & $0.7332^{* * *}$ & -0.0571 & -0.0445 & -0.06300 & 0.08477 & $-0.4589^{* * *}$ & 1 & \\
\hline Year $_{t}$ & $-0.3671^{* * *}$ & $0.4251^{\text {***}}$ & -0.0009 & 0.0780 & -0.0462 & $0.2778^{* *}$ & $-0.3850^{* * *}$ & -0.0268 & 1 \\
\hline
\end{tabular}

Note: ${ }^{* * *},{ }^{* *}$ and ${ }^{*}$ indicates significant at $1 \%, 5 \%$ and $10 \%$ level of significance based on t-statistics

The result of table 3 shows that the debt rate, the size of the company, the growth opportunities are correlated with the return on total assets. However, to affirm that these factors have an impact on the performance of the company, it is necessary to continue conducting a regression model (see Table 3 ).

\subsection{Choose the Model Estimation Method}

The result of a regression to the relationship between the debt ratio and the enterprise performance is based on the estimation method according to the Ordinary Least Square Regression Model (OLS), the fixed Effects Regression (FEM), and the Random Effects Models (REM). These models are in existence due to variables that are not observed in OLS estimation method, table 4 displays the test results by the FEM and REM model, which model will be selected will rely on the results of the Hausman inspection, resulting in statistical value with greater Prob $=0.8938>0.05$, thus to be able to conclude with a random impact model, prefer 
the Fixed Impact Model. However, when a defect test of a model exists for a self-correlation defect (Prob $=0.0092<$ 0.05 ), if using the regression equation with a random impact, the model will be deflected, so using the appropriate model can adjust the problem as an estimation of GLS. Due to the change in variance, it is advisable to use the appropriate model which may be the primary issue with using the General Least Squared Estimation Model (GLS).

\subsection{Regression Results}

Table 4 shows the regression results of FEM, REM, and GLS. Among the independent variables used in the model, only 5 variables help explain the dependent variable. They include LEV, $\mathrm{FCF}_{\mathrm{t}-1}$, Growth, TobinQ. Variables that do not affect ROA are Size, Oper and Year (see Table 4).

The results show that there is a relationship between the ratio of debt and the enterprise performance belonging to the joint stock companies of Vietnam national coal and mineral industries, which can be observed from the model which will show the coefficient of - 0.15 and statistically significant at the level of $1 \%$. The results of the study show that in the enterprises of Vietnam National Coal and Minerals Industries, with the increasing debt rate, the enterprise performance of the business decreases, the same results have been found in the study of Zhang (2017) and Tran (2017). These results prove that the relationship between the ratio of debt and the enterprise performance has a counter-dimensional relationship, which is that when the company's debt percentage increases, the results of the business's performance decreases. In accordance with the results of research in other enterprises participating in Vietnam securities market, especially in the current situation when the economy is struggling, businesses are finding it difficult consuming coal, therefore there is a need to mobilize capital from outside to overcome the decreasing enterprise performance. For some coal companies, it is not always the case that the loans taken by the subsidiaries are mainly from the parent companies.

Table 4: Regression results show the relationship between the debt ratio and enterprise performance

\begin{tabular}{|c|c|c|c|}
\hline Var & FEM & REM & GLS \\
\hline \multirow{2}{*}{ LEV } & $-0.150^{* * *}$ & $-0.151^{* * *}$ & $-0.150^{* * *}$ \\
\hline & $(-6.73)$ & $(-6.94)$ & $(-7.34)$ \\
\hline \multirow{2}{*}{$\mathrm{FCF}_{\mathrm{t}-1}$} & $-0.0310^{*}$ & $-0.0288^{*}$ & $-0.0288^{*}$ \\
\hline & $(-1.82)$ & $(-1.88)$ & $(-1.99)$ \\
\hline \multirow{2}{*}{$\mathrm{FCF}_{\mathrm{t}}$} & 0.0144 & 0.018 & 0.018 \\
\hline & $(0.82)$ & (1.06) & (1.13) \\
\hline \multirow{2}{*}{ Growth $_{t}$} & 0.0176 & $0.0223^{* * *}$ & $0.0223^{\text {***}}$ \\
\hline & $(1.62)$ & $(2.20)$ & (2.23) \\
\hline \multirow{2}{*}{ Size $_{t}$} & 0.00092 & 0.00102 & 0.00102 \\
\hline & $(0.43)$ & $(0.50)$ & $(0.53)$ \\
\hline \multirow{2}{*}{ Oper $_{t}$} & 0.007 & 0.00587 & 0.00587 \\
\hline & $(0.11)$ & $(0.09)$ & $(0.09)$ \\
\hline \multirow{2}{*}{ Tobin $_{t}$} & $0.0448^{*}$ & $0.0467^{* *}$ & $0.0467^{* *}$ \\
\hline & (1.94) & (2.07) & (2.18) \\
\hline \multirow{2}{*}{ Year $_{t}$} & 0.00956 & 0.00965 & 0.00965 \\
\hline & $(0.84)$ & $(0.86)$ & $(0.91)$ \\
\hline \multirow{2}{*}{ _Cont } & 0.0542 & 0.0469 & 0.0469 \\
\hline & $(1.13)$ & $(1.00)$ & (1.06) \\
\hline
\end{tabular}

Note: ${ }^{* * *},{ }^{* *}$ and ${ }^{*}$ indicates significant at $1 \%, 5 \%$ and $10 \%$ level of significance based on t-statistics 
The control of the use of loans from companies is not closely related to the loan's effectiveness. The use of many loans is not good. For coal mining joint stock companies, the deeper they mine, the higher the cost. So, the more loan a company has, the lower the ROA.

In variable control, the year t-1 lagged free cash flow $\left(\mathrm{FCF}_{\mathrm{t}-1}\right)$ has a negative impact on ROA at a $10 \%$ significance level. As the free cash flow of the year t-1 increases, the return on total assets tends to decrease and vice versa. This is consistent with Jensen's free cash flow theory. The Sale growth of the company, investment opportunities are positively related to the performance of the business and have statistical significance. However, other variables such as the size of the business, the ratio of operating costs, the number of years of establishment of the business, all show a positive relationship with the ROA but do not show statistical significance.

\section{Conclusions}

The study uses table data including 85 observations of joint stock companies of Vietnam national coal and mineral industries for the period $2014-1018$ to study the influence of the debt ratio on the enterprise performance (Measured by ROA). The results of the research show that the debt ratio has a negative impact on the enterprise performance, besides the firm performance are positively affected by the company's growth rate and investment opportunities and are negatively affected by the company's pre-period free cash flow.

The results of the study pointed out that the administrators of the Vietnam national coal and mineral industries should be aware of the impact of the debt ratio for the business efficiency of the business, or in other words, they should understand the the influence of capital structure in the enterprise to business efficiency. Currently, the debt capital of companies, most of which accounts for quite a high proportion of the total capital (most observations have a ratio of over $50 \%$ ), the higher the debt rate, the more the enterprise performance decreases, the higher the debt rate, the company is at risk of losing its own authority. Therefore, administrators should consider alleviating the ratio of debt in the structure of the company, using the increased mobilization of capital from profits and capital contributions from owners. This is the form of mobilization that the enterprises can mobilize in large quantities at a fixed capital price for a long time, and not worry about capital cost depending on market transformation, thereby contributing to improve the efficiency of the business. Through the results of research, authors propose subsequent research direction can expand the study of capital structure of enterprises affecting the investment activities of enterprises of Vietnam national coal and mineral industries in particular and in the business of the securities market participants in general.

\section{References}

Altuwaijri, B. M., \& Kalyanaraman. L. (2020). CEO EducationPerformance Relationship: Evidence from Saudi Arabia. Journal of Asian Finance, Economics and Business, 7(8), 259-268. https://doi.org/10.13106/jafeb.2020.vol7.no8.259

Berger, A., \& Patti, E. B. D. (2006). Capital structure and firm performance: A new approach to testing agency theory and an application to the banking industry. Journal of Banking \& Finance, 30(4), 1065-1102. doi:10.1016/j. jbankfin.2005.05.015

Bhaduri, S. N. (2002). Determinants of corporate borrowings: Some evidence from the Indian corporate. Journal of Economics and Finance, 26, 200-215. doi:10.1007/BF02755986.

Dessi, R., \& Robertson, D. (2003). Debt, incentives and performance: Evidence from UK panel data. Economic Journal, 113(490), 903-919. https://doi.org/10.1111/1468-0297.t01-1-00159

Donaldson, G. (1961). Corporate debt capacity: A study of corporate debt capacity. Cambridge, MA: Division of Research, Harvard School of Business Administration.

Dong, L. (2006). The effect of structural difference of debt financing on performance of listed companies. Journal of Zhongnan University of Economics and Law, 4-9. [Chinese].

Jensen, M. C., \& Meckling, W. H. (1976). Theory of the firm: Managerial behavior, agency costs and ownership structure. Journal of Financial Economics, 3(4), 305-360, https://doi. org/10.1016/0304-405X(76)90026-X.

Johl, S. K., Kaur, S., \& Cooper, B. J. (2015). Board Characteristics and Firm Performance: Evidence from Malaysian Public Listed Firms. Journal of Economics, Business and Management, 3(2), 239- 243

Majumdar, S. K., \& Chhibber, P. P. (1999). Capiatal structure and performance: Evidence from a transition economy on an aspect of corporate govermance. Public Choice, (98), 287-305. https://doi.org/10.1023/A:1018355127454.

Mo, S. (2008). An empirical study on Capital structure and profitability: Based on China's real estate industry. Communication of Finance and Accounting, (8), 15-17. [Chinese].

Modigliani, F., \& Miller, M. H. (1958). The cost of capital, Corporation Finance and the theory of investment. American Economic Review, 48(3), 261 - 297. https://www.jstor.org/ stable/1809766

Modigliani, F., \& Miller, M. H. (1963). Corporate income taxes and the cost of capital: A correction. The American Economic Review, 53(3), 433 - 443. https://doi.org/10.46281/afbr. v3i1.244.

Mukhibad, H., Subowo, S., Maharin, D. O., \& Mukhtar, S. (2020). Determinants of Debt Policy for Public Companies in Indonesia. Journal of Asian Finance, Economics, and Business, 7(6), 29-37. https://doi.org/10.13106/jafeb.2020. vol7.no6.029 
Nguyen, A. H., Pham, H. T., \& Nguyen, H. T. (2020). Impact of working capital management on firm's profitability: Empirical evidence from Vietnam. Journal of Asian Finance, Economics and Business, 7(3), 115-125. https://doi.org/10.13106/ jafeb.2020.vol7.no3.115.

Nguyen, C. T., Bui, C. M., \& Pham, T. D. (2019). Corporate capital structure adjustments: Evidence from Vietnam stock exchange market. Journal of Asian Finance, Economics and Business, 6(3), 41-53. https://doi.org/10.13106/jafeb.2019. vol6.no3.41

Nguyen, P. A., Nguyen, A. H., \& Nguyen, P. V. (2019). The relationship between productivity and firm's performance: Evidence from listed firms in Vietnam stock exchange. Journal of Asian Finance, Economics and Bussiness, 6(3), 131-140. https://doi.org/10.13106/jafeb.2019.vol6.no3.131.

Nguyên, T. D. K., \& Ramachandran, et al. (2006). Capital structure in small and medium sized enterprises: The case of VietNam. ASEAN Economic Bullentin, 23(2), 192-209. https://doi. org/10.1355/ae23-2d.

Nguyen, T. N. L., \& Nguyen, V. C. (2020). The determinants of profitability in listed enterprises: A study from Vietnamese stock exchange. Journal of Asian Finance, Economics and Business, 7(1), 47-58. https://doi.org/10.13106/jafeb.2020. vol7.no1.47.
Onaolapo, A. A., \& Kajola, S. O. (2010). Capital structure and firm : Evidan from Nigeria. European Journal of Economics, Finance and Administrative, 25, 70-80.

Rahman, M. M., \& Saima, F. N. (2018). Efficiency of board composition on firm performance: Empirical evidence from listed manufacturing firms of Bangladesh. Journal of Asian Finance, Economics and Bussiness, 5(2), 53-61. https://doi. org/10.13106/jafeb.2018.vol5.no2.53

Tran, N. B., \& Nguyen, D. H. (2017). Analyze the impact of capital structure on the performance of joint stock companies in Thua Thien Hue province. Journal of Economics and Management Science, (4), 1-14. [Vietnamese]. https://csdlkhoahoc.hueuni. edu.vn/data/2018/12/Bai_bao_-_Co_cau_von.pdf.

Xiong, J. P. (2013). Capital structure and enterprise performance - The empirical analysis of auto industry in China. Journal of Chongqing University of Science and Technology, 27(7), 4249. [Chinese].

Zeitun, R., \& Tian, G. G. (2007). Capital structure and corporate performance evidence from Jordan. Australasian Accounting Business \& Finance Journal, 1(4), 40-61. doi:10.14453/aabfj. v1i4.3.

Zhang, S. (2017). Conflict of Interest. Debt Financing. Capital Structure: A review. Journal of Chongqing Technology and Business University, 30(2), 23-29. [Chinese]. 